\title{
THE EFFECT OF USING EDMODO APPLICATION ON THE STUDENTS' WRITING SKILL OF ANALYTICAL EXPOSITION TEXT AT SMAN 4 PALANGKA RAYA
}

\author{
Enggal Pinanggih \\ University of Palangkaraya \\ enggalizard@gmail.com \\ Ristati \\ University of Palangkaraya \\ Tatiris795@gmail.com \\ Wahyuningsih Usadiati \\ University of Palangkaraya \\ wahyuusadiati@edu.upr.ac.id
}

\begin{abstract}
This research was conducted to find out the effect using Edmodo application on the students' writing skill of analytical exposition text at SM AN 4 Palangka Raya. Data of the students score of writing Analytical Exposition text was collected using writing test, and the hypothesis testing was examined based on t-test for normally because the data distribution was normal. A test in form of writing analytical exposition text was used the instrument to collect the data needed. Then, the data were analyzed by using parametric statistic dependent sample $T$ - test because the data were normally distributed. The writer took conclusion based on statistical result. The result of this research shows that the critical value for students $T$ distribution was 1.734 the critical value t0 was $t_{05}\{19\}=1.729$. Because 1.734 is greater than 1.729, null hypothesis was rejected. Thus, it can be concluded that there was significant effect of using Edmodo Application in writing Analytical Exposition Text gained by eleventh grade of SMAN 4 Palangka Raya. Thus, Edmodo Application had been successful in improving students' writing ability of Analytical Exposition text. The researcher suggest that the teacher should provide an appropriate media in teaching English, especially for Analytical Exposition Text and made Edmodo Application as reference to him/her to use it for making students' attracted to the material.
\end{abstract}

Keywords: Edmodo, ELT Media. 


\section{INTRODUCTION}

In teaching and learning process, difficulties are not avoidable among the students. Based on the previous observation at SMAN 4 Palangka Raya, the researcher found out that the students in senior high school are having many problems, especially in writing. Half of them confessed writing is too hard. When they did write task, they mostly are making some errors in organizing the idea, and arranging the sentence. They do not apply the generic structure and language feature of the Analytical Exposition text as well. Although, the students were given some explanations of how to arrange Analytical Exposition Text, they still did not understand well. Students need an additional motivation to write.

Teacher may use Edmodo to attract students' interest. Edmodo can be a good media in teaching writing. As with any other social network, Edmodo is accessible free on the site www.edmodo.com. Edmodo aims to help educators utilize social networking facilities in accordance with the conditions of learning in the classroom. Edmodo is designed to create interactions between teachers and students that emphasizes rapid communication, polls, assignments, share ideas, and many more things. As an educator, Edmodo provides a feature to share files, links, tasks and grade. For student, the feature in Edmodo are students can communicate directly with the teacher, discuss with other students, submit assignments directly and many more. Have an appearance like Facebook interaction systems, Edmodo teach students about responsibility and manner so that when the time comes, they can be social networking users who are responsible. Moreover, indirectly they also learn to express opinions in a structured and writing. Edmodo also comes with lots of games and applications that help students to learn with interactive and fun. Using Edmodo in teaching writing can be motivating. Many learners simply like using the computer. Using Edmodo, students and teachers can reach out to one another and connect by sharing ideas, problems, and helpful tips. A teacher can assign and grade work on Edmodo; students can get help from the entire class on Edmodo. It is a safe environment.

\section{LITERATURE REVIEW}

There are numerous teaching media that can be applied in teaching writing either traditional media or modern/digital media. In the context of teaching writing, Edmodo is one of the effective tools. Accordingly, Edmodo is a free and secure learning platform which is free of advertisements, games and other distractions used to provide a simple way for teachers to create and manage online classroom, and enable students to connect with teacher and other students anywhere and anytime (Balasubramanian, Jayakumar, \& Fukey 2014; Thongmak, 2013; Shams Abadi, Ahmadi, \& Mehrdad, 2015; Al-Khatiri, 2015). As with any other social network, Edmodo is accessible free on the smartphone with download Edmodo in Play Store or AppStore. Edmodo aims to help educators utilize social networking facilities in accordance with the conditions 
of learning in the classroom. Using Edmodo in teaching writing can be motivating. Many learners simply like using the smartphone. According to Barrett and Sharma (2007:50), they like multimedia exercise, as they can proceed at their own place. They can make their own choices as to how to work through the materials. Using technology in teaching

English language is very common today. In teaching writing, Edmodo has some advantages as follows: (1) it offers quick access to writing materials and assignments, (2) combined with particular approach or method or technique, Edmodo leads students to have better organization in writing, (3) Edmodo facilitates either teacher to give feedback on students' shared writing, or students to receive feedback on their writing from their peers and the teacher to make it as considerations in revising and editing their writing, and (4) Edmodo makes students more interested in writing (Stroud, 2010; Balasubramanian, Jayakumar, \& Fukey, 2014; Purnawarman, Susilawati, \& Sundayana, 2016; Shams-Abadi, Ahmadi, \& Mehrdad, 2015).

Based on the definition of Edmodo above, we can conclude, Edmodo is an educational application that takes the ideas of a social network and makes it appropriate for a classroom. Using Edmodo, students and teacher scan reach out to one another and connect by sharing ideas, problems, and helpful tips. A teacher can assign and grade work on Edmodo; students can get help from the entire class on Edmodo. Edmodo encourages the learning process through the interaction with contents, information, and assignment on the website; meanwhile, students can apply post for discussion and giving opinion.

\section{RESEARCH DESIGN}

This research adapted and applied One Group Pretest-Posttest Design. By adding the pretest in the research design, it provided an information that concerned about what might be happen if the treatment will not occur (Shadish et al: 2002). Therefore, a single pretest observation was done on a group before the treatment. Then, the treatment (Edmodo application) had been done twice. After that, a single posttest observation on the same measure meant was conducted.

The first, the sample of the research will be given a test (pre-test) before the treatment to find out their score in writing analytical exposition text. Second, the treatment activity which Edmodo Application was used to terms and learn Analytical Exposition Text three times, and use post-test activity. So, the description of this research design is figure and in figure.

\section{Figure One Group Pretest-Posttest Design}

(Shadish et al: 2002) 


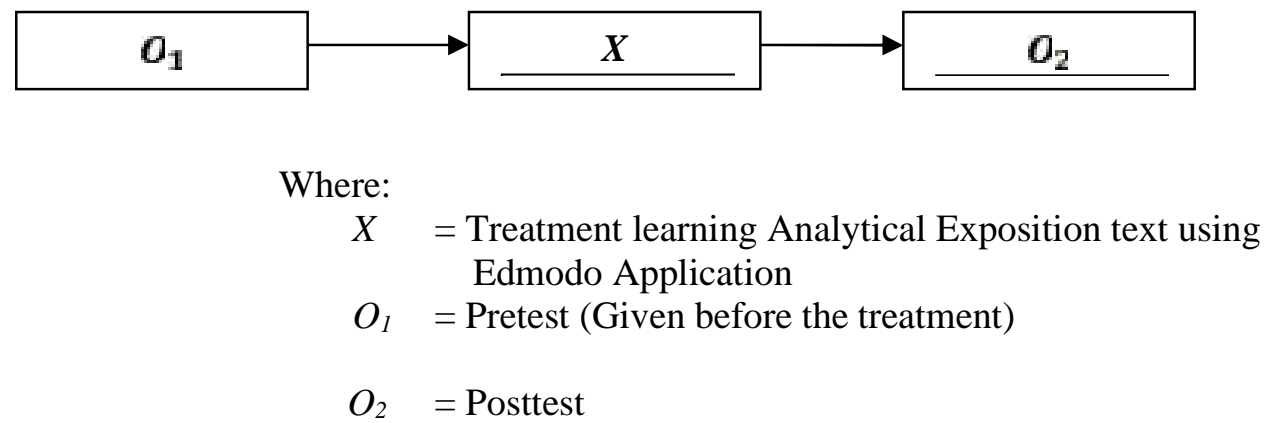

\section{DISCUSSION}

This part discusses the result of hypothesis testing and examines it based on the research objective. In this section the researcher discusses the result of the research about the effect of using Edmodo application on the student's writing skill of analytical exposition text. The objective of the research is to find out whether or not the use of Edmodo Application effect on the students' writing of Analytical Exposition Text achievement.

In analyzing the data, this research used the Lilliefors test to see whether the data of both pre-test and post-test conformed to a normal distribution or not. The result of the Lilliefors test conforms to normal distribution both pre-test and posttest. And then the researcher did the parametric statistic Dependent Sample t-test.

The result of critical value for students $t$ distribution table (on appendix) showed that the critical value of test statistic is $t=6,62$ the critical value $t 0$ is $t_{05}\{19\}$ $=1.729$. Because 1.729 is greater than 6.62 , we rejected $\mathrm{H}_{0}$. The result is statistically significant at the 5\% (0.05) level. Means the null hypothesis was rejected. The alternative hypothesis as follows:

\section{$\mathrm{H}_{\mathrm{a}}$ : The students' achievement of writing Analytical Exposition Text is} better after use Edmodo Application.

The previous research which used true-experimental research found out the effective use of Edmodo in writing a analytical exposition. Meanwhile this research used One Group Pre-test Post-test design to obtain the empirical evidence about the effect of using Edmodo application on the students' writing skill of analytical exposition text. Furthermore, the research conducted by previous research was emphasized to find out the improvement of the students in writing narrative while this research only focused on the effect of Edmodo application in writing analytical exposition text. Both researches show similar results that using Edmodo application gives significant effect on writing the text.

\section{CONCLUSION}


The result showed that the effect of using Edmodo Application helped students improve their ability in writing analytical exposition text. Based on the observation, the students' seemed excited when they used Edmodo, they were very enthusiastic to write analytical exposition text. So, it proved that using Edmodo Application as alternative media in helping students improve their writing skill in writing analytical exposition text. As a result, their scores in post - test improved compared to the result of their pre - test. The result of test calculation showed that score of T's was lower than the critical value of $t$ test. It means that the null hypothesis $\left(\mathrm{H}_{0}\right)$ was rejected and alternative hypothesis $\left(\mathrm{H}_{\mathrm{a}}\right)$ was accepted. Therefore, there was a significant effect of the use of Edmodo application on the students' writing skill of Analytical Exposition Text.

\section{REFERENCES}

Abadi, Bita. Bahrami. Shams. 2015. The Effect of E dmodo on EF L Learners' Writing Performance. Department of English, Hamedan Branch, Islamic Azad University, Science and Research Campus, Hamedan, Iran.

Adietama, L. 2014. The Effectiveness of Using Short Movie to Improve the Students' Ability in Writing Narrative Text. State Islamic Institute (IAIN) Tulungagung.

Azrah, M. 2017. Penerapan Strategi Think Talk Write (TTW) Dalam Pembelajaran Kooperatif Untuk Meningkatkan Hasil Belajar Matematika Siswa Kelas III SD Negeri 009 Tembilahan. Jurnal Primary Program Studi Pendidikan Guru Sekolah Dasar Fakultas Keguruan dan Ilmu Pendidikan Universitas Riau Volume 6 Nomor 1

Bertram, C. et al. 2010. Using Media in Teaching. South Africa: South African Institute for Distance Education

Diantari, N. W. D. 2015. The Effect Of The Integration Of Edmodo On The Writing Competency of The Tenth Grade Students Of Smk Negeri 1 Tampaksiring. Universitas Pendidikan Ganesha Singaraja. https://ejournal.undiksha.ac.id/index.php/JPBI/article/download/15066/92 23 (pp.1-8)

Dewi, P. 2012. Improving Students' Ability to Write Analytical Exposition Text Using Youtube's Video. Thesis (pp.37-38). https://digilib.uns.ac.id/dokumen/download/28102/NTkzOTI=/ImprovingStudents-Ability-to-Write-Analytical-Exposition-Text-Using-YoutubesVideo-a-Classroom-Action-Research-in-the-Eleventh-Grade-Students-ofSMAN-9-Purworejo-in-the-20102011-Academic-Year-abstrak.pdf （pp.142) 
Fauzi, A. 2017. The Effect of Edmodo on Students' Writing Skill in Recount Text. Department of English Education, Faculty of Teacher Training and Education, Sebelas Maret University, Surakarta. https://jurnal.uns.ac.id/ijpte/article/view/5038 (pp.74-79)

Fakultas Keguruan dan Ilmu Pendidikan, Universitas Palangka Raya. 2017. Pedoman Penulisan Skripsi. Palangka Raya: FKIP UPR.

Irawan,A.Fitri,Syapei,Marlina.2018.Students' Ability in Writing An Analytical Exposition Text. JELT vol 7.no.1 March 2018(pp.169-175)

Noviana, Okke. 2015. The Effective Use of Edmodo In Writing A Narrative Text in Senior High School. English Education Study Program Language and Art Department Teacher Training and Education Faculty Tanjungpura University.https://media.neliti.com/media/publications/216840-theeffective-use-of-edmodo-in-writing-a.pdf (pp.3-15)

Panjaitan, Siti. Rukmana. 2018. The Effect of Using English Magazineon Achievement in Writing Analytical Exposition Te nxt at Second Students' Students of SMA Islam Al-Ulum Terpadu Medan. Department of Grade Education Faculty of Tarbiyah Science and Teachers Training State Islamic University of North Sumatera. http://repository.uinsu.ac.id/4052/1/SKRIPSI\%20SITI\%20RUKMANA\% 20PANJAITAN.pdf (pp.1-42)

Setiawan, A. 2019. The Effect of Lyrics training on Students' Ability in Speaking 3 of English Education Study Program of University of Palangka Raya.

Setiawan, A. 2019. An Analysis on Students' Writing of Descriptive Text at The Tenth Grade of SMK N 5 Palangkaraya.

Shobikah, N. 2013. The Importance of English Language in Facing ASEAN Economic Community (AEC).Universitas Nahdlatul Ulama (UNU) West Kalimantan. https://jurnaliainpontianak.or.id/index.php/atturats/article/download/873/47 $\underline{5}$

Sukmahidayanti, T. 2015. The Utilization of Instructional Media in Teaching English To Young Learners (A Case Study of an Elementary School Teacher in Bandung). Journal of English and Education, 3(2): 92-93.

Sulisworo, D. Rahayu, T. and Akhsan, N. R. 2016. The Students' Academic Writing Skill After Implementing Blended Learning Using Facebook. Information Technologies and Learning Tools, 56(6): 177-178. Accessed on https://www.researchgate.net/publication/324940574

Tanriverdi, B. and Apak, O. 2008. Culture and Language Teaching Through Media. Published Thesis. Kocaeli University. 
THE EFFECT OF USING EDMODO APPLICATION ON THE STUDENTS' WRITING SKILL OF ANALYTICAL EXPOSITION TEXT AT SMAN 4 PALANGKA RAYA

Tileston, D.W. 2003. What Every Teacher Should Know about Media and Technology. Thousand Oaks, United States: Corwin Publish. 